emner. Hvis Williams havde fokuseret mere direkte på 'Guds ånd' ('Helligånden'), og hvis han havde suppleret sit jødiske blik med et græsk-romersk blik fra samtidig filosofi (in casu stoicismen), ja så ville han have fået øje på en mere systematiseret forståelse hos Paulus, end tilfældet nu er, både af åndeverdenen som helhed og af dens betydning for kristologien, soteriologien og menighedslivet.

Grundet den anførte mangel $\underline{\text { iii }}$ tror jeg ikke, Wayne Meeks ville mene, at Williams' bog er den fuldstendige opdatering af Dibelius' klassiker. Og grundet den anførte mangel iv vil jeg anbefale den interesserede læser at studere Williams - og så gå videre til min egen bog!

Troels Engberg-Pedersen

\title{
Jorunn Økland
}

Paulus' Brev. Innledende essay og introduksjoner ved Jorunn Økland. Oversettelse ved Det Norske Bibelselskap. Verdens hellige skrifter. Oslo: Bokklubben 2010. LXXIII + 238 s. NOK 409.

Dette er en prægtig bog. Den vil tale til enhver dansker med en genuin interesse for Paulus, som også læser norsk. Den burde også oversættes til dansk, så intet kan forhindre, at den også bliver læst herhjemme. Bogen henvender sig til den 'alment interesserede', men også specialister på Paulus (og ikke mindst Paulusreceptionen) vil have stort udbytte af at læse den.

Bogen rummer et indledende essay på i alt 66 (små) sider samt forholdsvis korte introduktioner til både de ægte Paulusbreve (i den kanoniske rækkefølge: Rom, 1 Kor, 2 Kor, Gal, Fil, 1 Thes, 2 Thes, Filemon) og 'Paulustraditionen' (Kol, Ephes samt de tre Pastoralbreve: 1 Tim, 2 Tim og Tit). Rækkefølgen skyldes nok, at selve oversættelserne er taget fra den norske Bibel. Men Økland burde i det mindste have angivet en bedre pædagogisk rækkefølge for læsningen af de syv ægte breve. Den foreslår jeg så her: 1 Thes, Fil, Filemon, Gal, 1 Kor, 2 Kor, Rom. Læser man på den måde, går man fra det enkle og lysende klare (og givetvis ældste brev af de syv): 1. Thessalonikerbrev - over det umådeligt rige, men ikke så konfliktstyrede Filipperbrev og det lille, charmerende Filemonbrev til de fire store 'hovedbreve', hvoraf de i teologisk henseende traditionelt tungeste breve, Galaterbrevet og Romerbrevet, omkranser de to uhyre levende og på alle måder centrale Korintherbreve.

Introduktionerne til de enkelte breve er veloplagte, kortfattede appetizers, som spiller fint sammen med det indledende essay. Det sidste er bogens hovedattraktion, simpelthen fordi det åbner for en ny måde at læse Paulus på, som nok er delvis velkendt i Danmark ('den nye Paulus'), men som også udvider med en række ikke-kristne filosoffers Pauluslæsninger fra de sidste 25 år og tillige gør det på en ny og fascinerende måde. Hermed er ikke sagt, at Økland glemmer hele Pauluslæsningen mellem apostlen selv og 'den nye 
Paulus'. Hun siger: "Denne innledningen har gått utenom den kirkelige resepsjonen av Paulus" (s. LXIX). Men det passer faktisk ikke. Hendes stærke fokus på receptionshistorien bruger med rette tid på receptionen af Paulus i den tidlige kirke op til den endelige kanondannelse i det 4. årh., på Luthers Pauluslæsning og meget mere fra den mellemliggende periode.

Alligevel er det forfriskende ved bogen dens helt moderne greb. Jeg citerer:

“Jeg begynner i det generelle, med kulturhistorien: Jeg har ønsket å vise at kirken ikke har monopol på Paulus, og at Paulusbrevene som kulturell tekst står utmerket godt på egne ben" (s. LXIX).

“Når Paulus' brev i vår tid opplever en ny renessanse i filosofi og kritisk teori, så er denne renessansen betinget av den totale kenosis (uttømming eller utslokning) av autoritet forbundet med ham. I forhold til de fleste lesere i dag er Paulus tilbake der han startet, som en som ble møtt med mistenksomhet. En som nettopp ikke hadde autoriteten, retten, tradisjonen eller den religiøse makten på sin side, men måtte argumentere alt han var god for. Kanskje [Giorgio] Agamben har rett, kanskje det først er nå vi igjen er i stand til å høre hva han sier?” (s. LXX).

Bag dette perspektiv ligger - som Økland med rette insisterer på (s. XLIII og LXXI) - det 'nye' Paulus-billede, som ser Paulus som en jøde blandt jøder, og som også i høj grad er blevet drevet frem af jødiske forskere (om end også af nordiske protestantiske forskere såsom Johannes Munck og Krister Stendahl): E.P. Sanders, Alan Segal (ikke nævnt), Mark Nanos og Daniel Boyarin. Og Økland hævder derfor med rette følgende:

"Det finnes selvsagt fortsatt forskere som søker nye svar på gamle spørsmål, men de som genererer de nye spørsmålene i dag, starter med den jødiske Paulus, og så knytter de seg opp mot et postmoderne (fra Lacan til Boyarin) eller et mer kontinentalfilosofisk ([Jakob] Taubes og Agamben) rammeverk. Denne utviklingen er bare en logisk konsekvens av «New Perspective»-forskningen, som slo fast at en lesning av Paulus i hans historiske kontekst er en lesning av den jødiske Paulus" (s. LXXI).

Og så drager Økland en række radikale konsekvenser:

"Det betyr at all annen lesning er appropriering [altså en 'indlemmelse' i ens egen dagsorden]. A studere kanoniseringsprosessene slik vi har gjort i denne innledningen ... er å studere hvordan en kristen appropriering ble «naturlig», hvordan det gikk til at Paulus retrospektivt ble utropt til «kristendommens andre grunnlegger» og «den første kristne forfatter».” (s. LXXI).

Og videre:

"Dersom Paulus ikke lenger er kristen [!], bliver den kristne bruken av ham en mer eller mindre tilfeldig tilleggsbruk [!]. Og hvis det er slik, vil det også si at annen appropriering er like mulig som den kristne approprieringen: Hva med en ateistisk lesemåte? ... Framtiden blir spennende!” (s. LXXII). Jo, det har Jorunn Økland ret i. 